\title{
臨床経験
}

\section{好中球減少症に合併した肚門周囲感染症に対する 切開ドレナージ術の検討}

\author{
亀田総合病院外科 \\ 杉本卓哉 三毛牧夫高賢樹 \\ 永田洋士角田明良加納宣康
}

好中球減少症に合併した肚門周囲感染症 9 例について疾患背景や症状, 所見さらに治 療法について検討した，症例は $18 〜 75$ 歳で男性 8 例，女性 1 例であった，基礎疾患は全 例血液疾患であり， 5 例が骨髄移植， 3 例が化学療法， 1 例が基礎疾患のために好中球 減少症を呈していた。全例発熱と肚門痛を認めたため精査を行い, 好中球減少症に合併 した肛門周囲感染症と診断した， 7 例で肛門の圧痛部位を切開，ドレナージした４例 で漿液性の排液を, 3 例で排膿を認めた。 1 例で肚門痛が再発し, 圧痛部位を再切開し, 再度漿液性の排液を認めた。再切開を行った 1 例を含め, 術後肛門痛に対するペインス ケールの改善と鎮痛薬の使用頻度が減少し, 解熱を認めた. 肛門の圧痛部位を積極的に 切開, ドレナージを行うことで解熱掞よび肛門痛の軽滅を認め, 感染の限局化を図るこ とができることが示唆された.

索引用語：好中球減少症, 肚門周囲感染症, ドレナージ

緒言

発熱性好中球減少症（febrile neutropenia, 以下 FN と略記) は化学療法や移植療法の重要な有害事象 であり, 重症化しやすいため適切な治療が必要であ る ${ }^{1)}$. 発熱の一因として肚門周囲感染症があげられ, これには外科医が関与する可能性がある。しかし本邦 においては, その治療法についての報告は皆無であり, 治療戦略の考察がなされていない可能性がある. 今回, 当院でFNに合併した肛門周囲感染症と診断した 9 例 に扔いて, 診断掞よび治療について検討を行ったので 文献的考察を含め報告する。

\section{対象および方法}

2005年から2011年の 7 年間に当院で経験した血液疾 患に起因したFNに合併した肛門周囲感染症 9 例を対 象とし, カルテレビューによって現疾患㧍よび好中球 減少症の原因, 治療, 肛門周囲感染症と診断した際の 理学的所見について検討した（Table 1).ささらに治 療抢よび治療経過について検討した（Table 2,3）.

2013年 1 月 16 日受付 2013 年 2 月 25 日採用

〈所属施設住所〉

干296-8602 鴨川市東町929
結 果

症例は18〜75歳で男性 8 例, 女性 1 例であった. 基 礎疾患は全例血液疾患であり，5例が骨髄移植後， 3 例が化学療法中であった。 1 例は原疾患ためにFNを 呈していた。全例腋窩温で37.5度以上の発熱と肛門痛 を認めたため精査を行い, 好中球減少症に合併した肛 門周囲感染症と診断した. 診断時の好中球数は全例 500/ $\mu 1$ 以下であり，FNの定義を満たしていた。 また 血小板数は9,000〜 42,000/ $\mathrm{mm}^{2}$ であった. The Multinational Association for Supportive Care in Cancer (MASSC) のスコアリングシステムでは 5 例が高リ スク (21未満)，4例が低リスク（21以上）であった2). 骨髄移植による症例では移植後 4 〜 17 日目に発症し, 化学療法による症例では15〜22日目に発症していた. 主訴は全例肛門痛であり, 発熱の平均2.7日前から肛 門痛を認めていた. 肚門視診では 6 例で明らかな異常 を認めなかった，肚門指診では全例圧痛を認め, 5 例 で硬結を触知した。画像検查は 7 例で施行しているが 6 例で膿瘍形成を認めず, 膿瘍を認めたのは 1 例のみ であった８例で血液培養検査が施行されているが, 陽性となったのは 2 例のみであった。 7 例で圧痛部位 を切開し, 切開・ドレナージを施行した. 切開・ドレ 
Table 1. Characteristics of patients.

\begin{tabular}{ccccccccc}
\hline Case & Age & Sex & $\begin{array}{c}\text { Underlying } \\
\text { disease }\end{array}$ & \multicolumn{2}{c}{$\begin{array}{c}\text { Received } \\
\text { treatment }\end{array}$} & MASCC & $\begin{array}{c}\text { Neutrophil count at } \\
\text { diagnosis }\left(/ \mathrm{mm}^{3}\right)\end{array}$ & $\begin{array}{c}\text { Platelet count at } \\
\text { diagnosis }\left(/ \mathrm{mm}^{3}\right)\end{array}$ \\
\hline 1 & 75 & M & AML & CT & day 16 & 19 & 290 & 42,000 \\
2 & 53 & M & ATL & BMT & day 4 & 19 & 160 & 37,000 \\
3 & 18 & M & Malignant lymphoma & BMT day 4 & 17 & 0 & 13,000 \\
4 & 34 & M & AML & BMT day 7 & 19 & 0 & 24,000 \\
5 & 48 & F & AML & BMT day 6 & 21 & 0 & 40,000 \\
6 & 40 & M & AML & CT day 22 & 21 & 0 & 22,000 \\
7 & 18 & M & Aplastic anemia & BMT day 17 & 21 & 0 & 9,000 \\
8 & 60 & M & MDS & \multicolumn{2}{c}{ B - } & 19 & 200 & 35,000 \\
9 & 42 & M & DLBCL & CT day 15 & 21 & 60 & 55,000 \\
\hline
\end{tabular}

MASCC : Multinational Association for Supportive Care in Cancer, F : female, M : male,

AML : acute myelogenous leukemia, ATL : adult T-cell leukemia, DLBCL : diffuse large B-cell lymphoma, BMT : bone marrow transplantation, CT : chemotherapy

Table 2. Characteristics of patients. (Continued)

\begin{tabular}{|c|c|c|c|c|c|}
\hline Case & $\begin{array}{c}\text { Chief } \\
\text { complaint }\end{array}$ & Anal inspection & $\begin{array}{l}\text { Digital rectal } \\
\text { examination }\end{array}$ & $\begin{array}{c}\text { Anoscope } \\
\text { examination }\end{array}$ & Image findings \\
\hline 1 & anal pain & n. p. & pain, induration & n. p. & no perianal abscess formation (CT) \\
\hline 2 & anal pain & n. p. & pain, induration & n. p. & no imaging study done \\
\hline 3 & anal pain & inflammatory & pain & n. p. & no perianal abscess formation (CT) \\
\hline 4 & anal pain & $\begin{array}{l}\text { inflammatory, } \\
\text { swelling }\end{array}$ & pain & n. p. & perianal abscess formation (CT) \\
\hline 5 & anal pain & n. p. & pain & n. p. & no perianal abscess formation (CT) \\
\hline 6 & anal pain & n. p. & pain, induration & reddening & no perianal abscess formation (CT) \\
\hline 7 & anal pain & $\begin{array}{c}\text { subcutaneous } \\
\text { abscess }\end{array}$ & pain & n. p. & no imaging study done \\
\hline 8 & anal pain & n. p. & pain, induration & anal fissure & no perianal abscess formation but anal fistula (MR) \\
\hline 9 & anal pain & n. p. & pain, induration & n. p. & no perianal abscess formation (CT) \\
\hline
\end{tabular}

ナージ後は，5例で翌日に解熱したが，症例 5 では 4 日目，症例 8 では15日目に解熱した。疼痛は全例 1 週 間以内に改善を認めた。症例 6 では再燃し, 初回切開 後12日目に再度切開・ドレナージを施行し，翌日に解 熱した。

\section{考察}

血液腫瘍疾患などにおいて, 好中球減少時における 発熱の原因の約 8 割は病原微生物に対する生体反応と 考えられている3 ${ }^{3}$. 起炎菌の約 8 割は患者の菌叢に由 来する内因性感染症とされるが， 6 割は感染部位が不 明である．また重篤になりやすいため迅速な対応が必 要である1)。これまでの報告では, FNのうち約 $1.9 \%$ が肛門周囲感染症であり，急性白血病の $7.9 \%$ が肚門 周囲感染症を発症したと報告されている4) 6)．また好 中球減少症に肛門周囲感染症を合併した場合の死亡率 は11〜 57\%とされている(4) 6).
一般に, 細菌感染が起こると急性の炎症反応として, 好中球が遊走し感染を局所で制御する. しかし好中球 減少時には遊走する好中球がないため感染が制御され ず，周囲へ波及したり菌血症に発展しやすい。また好 中球や壊死細胞などからなる膿も形成されないことも あり診断や治療に苦慮する。

FNの原因としての肛門周囲感染症の場合，急性炎 症反応のために肚門の疼痛や浮腫，発赤などの症状や 所見を呈することが多いが，必ずしも膿瘍を形成する とは限らない( $)$. 外科医が診察する前に発熱性好中球 減少症診療ガイドラインに従い，抗菌薬治療が開始さ れていることが通常であるが，適切な判断がなされな いと壊死性筋膜炎や敗血症へと発展する可能性があ $る^{11}$ 。画像検査は膿瘍の有無を確認すること以外に, 他に熱源がないか確認するためにも非常に重要であ る。肛門周囲に膿瘍を認めなくても他に熱源と思われ 
Table 3. Treatement and the prognosis of patients.

\begin{tabular}{|c|c|c|c|c|c|c|c|}
\hline \multirow[b]{2}{*}{ Case } & \multirow{2}{*}{$\begin{array}{c}\text { Bacteria } \\
\text { detected from } \\
\text { blood culture }\end{array}$} & \multirow{2}{*}{$\begin{array}{l}\text { Bacteria detected } \\
\text { from the culture of } \\
\text { surgical site }\end{array}$} & \multirow[b]{2}{*}{ Antibiotics } & \multirow[b]{2}{*}{$\begin{array}{l}\text { Surgical } \\
\text { procedure }\end{array}$} & \multicolumn{2}{|c|}{ Prognosis } & \multirow[b]{2}{*}{ Others } \\
\hline & & & & & $\begin{array}{l}\text { Declining } \\
\text { of fever }\end{array}$ & $\begin{array}{l}\text { Relief } \\
\text { of pain }\end{array}$ & \\
\hline 1 & negative & $\begin{array}{c}\text { E. faecalis } \\
\text { E. faecium } \\
\text { S. epidermidis } \\
\text { P. aeruginosa }\end{array}$ & meropenem & drained & POD1 & POD1 & \\
\hline 2 & negative & no cultivation & cefepime & - & - & 4 days later & \\
\hline 3 & E. coli & E. faecalis & meropenem & - & $\begin{array}{l}\text { the day after } \\
\text { abscess } \\
\text { destruction }\end{array}$ & $\begin{array}{l}\text { the day after } \\
\text { abscess } \\
\text { destruction }\end{array}$ & $\begin{array}{l}\text { Formed abscess, then } \\
\text { spontaneous drainage } \\
\text { occurred } 6 \text { days later }\end{array}$ \\
\hline 4 & negative & $\begin{array}{l}\text { E. faecium } \\
\text { E. coli } \\
\text { S. haemolyticus }\end{array}$ & $\begin{array}{c}\text { meropenem } \\
\text { vancomycin } \\
\text { metronidazole }\end{array}$ & drained & POD1 & POD3 & \\
\hline 5 & negative & no cultivation & $\begin{array}{c}\text { cefepime } \\
\text { metronidazole }\end{array}$ & drained & POD4 & POD6 & \\
\hline 6 & $\begin{array}{c}\text { Klebsiella } \\
\text { pneumoniae }\end{array}$ & no cultivation & $\begin{array}{l}\text { meropenem } \\
\text { vancomycin }\end{array}$ & drained & POD1 & POD3 & $\begin{array}{l}\text { recurred on POD12 } \\
\text { and incised again }\end{array}$ \\
\hline 7 & no cultivation & no cultivation & $\begin{array}{c}\text { cefepime } \\
\text { vancomycin }\end{array}$ & drained & POD1 & POD1 & \\
\hline 8 & negative & P. aeruginosa & meropenem & drained & POD15 & POD4 & \\
\hline 9 & negative & no cultivation & $\begin{array}{l}\text { piperacillin } \\
\text { /tazobactam }\end{array}$ & drained & POD1 & POD1 & \\
\hline
\end{tabular}

る所見がなく，その他の所見から肛門周囲感染症が疑 われる場合には, 肛門周囲感染症として治療を行うこ とが必要である。自験例では 9 例のうち 6 例 $(67 \%)$ では画像検查で膿瘍を形成していなかった。また画像 検査を施行しなかった 1 例（症例 2 ）においても身体 所見上膿瘍形成を認めなかった。これらの 7 症例では 他に熱源となりうる症状や所見がなく，肚門痛や肛門 の所見から好中球減少症に合併した肚門周囲感染症と 診断した。なお, 肛門痛に関しては発熱の 2,3 日前 より認めることがあると報告されており注意が必要で あるが，自験例においても発熱に先行して肛門痛を認 めた6).

高い死亡率のため，FNにおける肚門周囲感染症に 対する治療法が海外では検討されてきた．報告の多く は, 発熱性好中球減少症に対する治療ガイドラインが
作成されたり, 様々な抗菌薬が登場する以前のもので ある，そのため死亡率などの数值をそのまま参考にす ることに抵抗はあるが, 現代に打いても適切に治療し なければならない疾患であることに変わりはない. 1980年前半までは出血や創傷治癒の問題から切開・ド レナージを含めた手術を控え, 抗菌薬や座浴による治 療が一般的であった ${ }^{7)}$. その後, 放射線による治療が 報告されたが, 抗菌薬との比較試験で有意な結果を示 すことができなかった7)8). しかし Barnesらが重症患 者に対して切開・ドレナージを施行し良好な結果をえ られたことを報告して以来, 早期の切開・ドレナージ が推奨されるようになった ${ }^{6 / 9)}$. これに対し，切開・ ドレナージの有無に関わらず，アミノグリコシド系抗 菌薬と嫌気性菌に対する抗菌薬を投与することで良好 な結果を得ることができたという報告や, 抗菌薬のみ 
で治療できる可能性があるので，外科治療は抗菌薬開 始後48時間以内に改善が認められない場合のみでよい とする報告もあり, 依然結論は出ていない10111)。一方, 本邦においては医学中央雑誌（1983年〜）を渉猟した 限り, 発熱性好中球減少症における肛門周囲感染症の 治療法についての報告は皆無であり，これまでエビデ ンスに基づいた治療がなされていなかった可能性があ る.

切開・ドレナージを行う利点として, 感染制御以外 に疼痛コントロールがあげられる。陰窩感染の他, 抗 癌剂による下痢などで直腸肚門の粘膜障害が起こり, 肛門周囲感染症を来すとされているが，排便時の肛門 痛は耐え難いものである。膿瘍を形成していなくても 感染部位を切開・ドレナージすることで疼痛を改善す ることができる ${ }^{4) 6}$. 自験例でも切開・ドレナージ後 に解熱し, 疼痛は早期に改善した。

外科医が，FNにおける肛門周囲感染症に対して切 開・ドレナージを躊躇する原因として, 診断が困難で あること以外に血小板減少に伴う出血の危険性や創傷 治癒の問題があげられる。手術に伴う合併症はなかっ たという報告がある一方, 術後出血をきたした報告も あり注意が必要である ${ }^{618) 12}$. 自験例では血小板輸血を 術直前に行い, $50,000 / \mathrm{mm}^{3}$ 以上にした状態で切開し た. 切開後は止血を確認できるまで30分以上圧迫する ことで術後出血は認めず安全に施行できた。治癒過程 においては，遅延する場合や痔瘦を形成する場合があ るが, Corfitsenらは治癒までの時間は非免疫抑制患 者と同等の頻度であったと報告している4). また Cohen らは骨髄移植患者に拈いて, 治癒過程はステロ イドの全身投与にも影響されなかったと報告してい $ろ^{13)}$.

\section{結 語}

以上，これまでの報告から，FNに合併した肛門周 囲感染症に対して, 発熱性好中球減少症診療ガイドラ インに従って治療を開始し, さらに全身状態や症状の 程度を含めた患者の状態や経過, MASSCによる予後 予測を参考に, 切開・ドレナージの介入時期を検討す ることが必要と考えられた。切開・ドレナージを行う 場合には血小板輸血や十分な止血操作で出血などの合 併症を防ぐことができるため, 重症例, 状態悪化例な どでは躊躇せずに外科的介入することが妥当であると 考えられた。

$$
\text { 文献 }
$$

1) Freifeld AG, Bow EJ, Sepkowitz KA, et al : Clini- cal practice guideline for the use of antimicrobial agents in neutropenic patients with cancer : 2010 update by the infectious diseases society of america. Clin Infect Dis $2011 ; 52$ : e56-93

2) Klastersky J, Paesmans M, Rubenstein EB, et al : The Multinational Association for Supportive Care in Cancer risk index : A multinational scoring system for identifying low-risk febrile neutropenic cancer patients. J Clin Oncol $2000 ; 18$ : $3038-3051$

3) Tamura K, Imajo K, Akiyama N, et al : Randomized trial of cefepime monotherapy or cefepime in combination with amikacin as empirical therapy for febrile neutropenia. Clin Infect Dis 2004 ; 39 (Suppl 1) : S15-24

4) Corfitsen MT, Hansen CP, Christensen TH, et al : Anorectal abscesses in immunosuppressed patients. Eur J Surg $1992 ; 158: 51-53$

5）金倉 護, 手島博文, 平山文也 : 急性白血病にお ける発熱原因の検討. 日血会誌 $1985 ; 48: 1514$ $-1521$

6) Barnes SG, Sattler FR, Ballard JO : Perirectal infections in acute leukemia. Improved survival after incision and debridement. Ann Intern Med $1984 ; 100: 515-518$

7) Sehdev MK, Dowling MD Jr., Seal SH, et al : Perianal and anorectal complications in leukemia. Cancer $1973 ; 31: 149-152$

8) Glenn J, Cotton D, Wesley R, et al : Anorectal infections in patients with malignant diseases. Rev Infect Dis $1988 ; 10: 42-52$

9) Buyukasik Y, Ozcebe OI, Sayinalp N, et al : Perianal infections in patients with leukemia : importance of the course of neutrophil count. Dis Colon Rectum $1998 ; 41: 81-85$

10) Lehrnbecher T, Marshall D, Gao C, et al : A second look at anorectal infections in cancer patients in a large cancer institute: the success of early intervention with antibiotics and surgery. Infection $2002 ; 30: 272-276$

11) Grewal H, Guillem JG, Quan SH, et al : Anorectal disease in neutropenic leukemic patients. Operative vs. nonoperative management. Dis Colon Rectum 1994 ; 37 : $1095-1099$ 
12) North JH Jr., Weber TK, Rodriguez-Bigas MA, et al : The management of infectious and noninfectious anorectal complications in patients with leukemia. J Am Coll Surg 1996 ; 183 : 322 - 328
13) Cohen JS, Paz IB, O’Donnell MR, et al : Treatment of perianal infection following bone marrow transplantation. Dis Colon Rectum 1996 ; $39: 981-985$

\title{
SURGICAL MANAGEMENT FOR PERIANAL INFECTION IN IMMUNOSUPPRESSED PATIENTS
}

\author{
Takuya SUGIMOTO, Makio MIKE, Kenju KO, Hiroshi NAGATA, \\ Akira TSUNODA and Nobuyasu KANO \\ Department of Surgery, Kameda Medical Center
}

Purpose : Treatment of perianal infection with febrile neutropenia is still controversial. The aim of this study is to investigate the efficacy of surgical intervention and the prognosis of patients with perianal infection with febrile neutropenia. By reviewing the previous literature, we searched for the appropriate treatment for this disease. Subjects \& Method : Consecutive nine patients with perianal infection with febrile neutropenia were retrospectively reviewed. Their ages ranged from 18 to 75 and there were eight men and one woman. Results : All patients were affected with hematological diseases with neutropenia. Five of them had undergone bone marrow transplantation, three, chemotherapy, and one who presented neutrspenia due to the underlying disease. All patients were diagonosed as having perianal infection with febrile neutropenia because of perianal pain and fever. Seven of nine patients underwent incision and drainage of the perianal region. Of the seven patients, serous discharge was noted in four patients and pus discharge, in the remaining three. One patient in whom perianal pain recurred required re-incision, with resultant serous discharge again. After the surgery, all seven patients were relieved from fever and perianal pain, and the infection was put under control. Conclusion : Surgical management for perianal infection with febrile neutropenia was effective in controlling infection and relieving the symptoms.

Key words : febrile neutropenia, perianal infection, drainage 